\title{
避航動作を考慮した場合の航路交差部の 交通容量についての一考察
}

\section{平 野 新太郎*}

A Consideration on the Traffic Capacity at the Crossing of a Sea Route When Collision-avoiding Maneuvers Are Taken into Account

Shintaro HIRANO

\begin{abstract}
When a vessel tries to cross a route, she seeks a gap in the queue of the vessels in the main route by means of collision-avoiding maneuver. As the result of this operation, that vessel turns her position to the right. In the narrow sea, the maginitude of this shift ( $\mathrm{Td}$ ) is the most important factor in determining the traffic capacity at the crossing. A certain equation can be established between $\mathrm{Td}$ and $\mathrm{T}_{\mathrm{w}}$, i.e., the relative waiting time, which is represented by the same formula as is used for the waiting time in crossing a road on land. Therefore, in case $\mathrm{T}_{\mathrm{w}}$ is given, $\mathrm{Td}$ can be obtained.

However, when the traffic is congested, the vessels in the main route form a number of queues and also the collision-avoiding maneuver of the crossing vessel varies according to the mutual relation among the vessels in the several queues formed in the main route. Therefore, in such a case, it is difficult to obtain Tw by the theoretical formula.

In this paper, the solution is sought by means of Monte Carlo Method; the probability curve of $\mathrm{T}_{\mathrm{W}}$ is presented; and the nature of this solution is discussed. Besides, $\mathrm{Td}$ is calculated from the result of this solution; the value thus obtained is ascertained to be very close to the value actually observed at the crossing; and examinations are made on the traffic capacity at this crossing.
\end{abstract}

\section{1. ま え がき}

陸上の道路では, 横断すべき道路に到達した歩行者は, その道路を通交する車両群の中に横断可能な時閒的な すき間を見出したときその道路を横断し，もしそのよらなすき間がないときはすき閒がやってくるまで待つ。こ のことは多くの人により研究され, 待ち時間の分布, 平均值などの式として与えられている。一方船舶が航路交 差部を横断する場合には, 避航動作により優先航路の通航船の寸き間を積極的にとらえて横断する。それゆえ船 舶の横断動作の解析は陸上の場合に比して上り複雑となることが予想され, かつ, 停止しての待ちは存在しない けれども，筆者はさきに ${ }^{(7)}$, 優先航路（以下主航路という）の船 $\mathrm{A}$ と，これを避航しつつ横断する従航路の船 $B$ において, 避航しなかったとしたときの B と Aの時間関係と, 避航したときの B と Aの時間関係の変化分を待ち 時間と考えると，陸上に晾ける待ち時間の式がそのまま適用されることを見出し，これを特に「相対待ち時閒」 と名付け，さらに，交差に每たっての船舶の時間閉塞領域 Tが $500 \sim 1,000$ トンのいわゆる小型船については 前 方1. 5分, 後方1.0分, 計 2.5 分であることを示したが. (1,000 3,000トンでは 3.0 分), 今回は 交差容量を求める ためこの結果をもとにして, 多数船舶航行時の待ち時間について考察を加え, 横断時の航跡の時間偏位量 $T d$ を 求めた。そしてその検証として宇高東航路の船舶の主航路横断時の $T d$ の分布と比較してみたが，良好な近似が 得られたので報告する。

* 海上保安大学校 (與市若葉町 $1-1$ ) 


\section{2. 変位時間 $\boldsymbol{T} d$ について}

図 1 は主航路を従航路の船Bが避航しつつ横断する状況を示す。図示の如く, 避航の結果船舶は本来のコ一ス から偏位する。避航動作の可能な海域は有限であるから，この偏位量と通航船舶量との関係を知ることが必要と なる。ところで避航しなかったとすればBは主航路の船 $\mathrm{A} の$ 前方 $t_{a}$ 分のところを通過することになるが，避航 の結果, $\mathrm{A} の ~\left(t_{b}+t_{c}\right)$ 分あとを通っている。すなわちこのときの相対待ち時間, つまり避航しなかったときにく らべてのB船のAに対するおくれ時間の堌加分 $T w$ は,

$$
T w=t_{a}+t_{b}+t_{c}
$$

となる。ここに

$$
\begin{aligned}
T d & =t_{a}+t_{b} \\
t_{c} & =t_{2}-t_{1}
\end{aligned}
$$

ただし $T d$ は偏位時間であって，単位を分とすれば, これに 1 分あたりの速度 $v$ (12)ット/hとすれば370 $m /$ 分）をかければ偏位量となる。すなわち偏位時間 とは偏位量を時間で表わしたものにほかならない。さ てこれらの式より

$$
T d=T w-\left(t_{2}-t_{1}\right)
$$

すなおち $T w$ と $t_{2}-t_{1}$ が与えられれば $T d$ は定まる ことになる。

ところで $T w$ の式としてこれまで用いたのは主航 路の船が 1 列の場合についてである。通常の通航状態 では通航量が比較的少ないので 1 列とみなして計算し てもさしつかえないが，交差容量を対象とするために は, 主航路の極限に近い状態での通航状況, 及び，そ のような状態のときの横断船の動作を考慮した $T w$ を 用いる必要がある。また $t_{2}$ は, 船の操縦性能, 操船 方法のちがいなどにより異なってくるが，ここでは一 応標準的な曲線を与えて，これを用いることにする。 以下順を追ってのべる。

\section{3. 時空平面による表現}

解析の便宜上, 以下にのベるような特別な時空平面 を考える。これは運動体の位置関係を明らかにするこ とを目的としたものであるため，運動体に対しては 2 次元の動きを許容する。それゆえ通常の時空平面とは 用い方が多少異なるので若干の説明を加える。これは 第 2 図に示すよらに縦軸に時間, 横軸に位置 $x$ をとっ たものでこれだけならば通常の時空平面と何等異なら ない。

いま $D, D_{1}^{\prime}, D^{\prime}{ }_{2}$ の如く単位時閒に 2 単位長だけ $x$ 軸方向に移動する点 $D$ を考えると, この点は $D$,

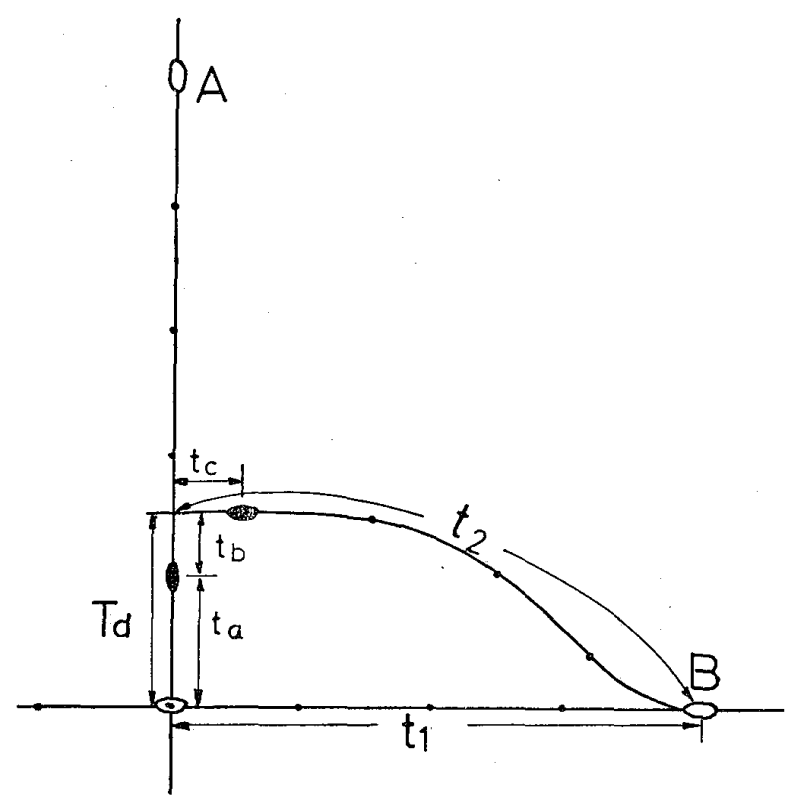

図 $1 T w$ と $T d$ の関孫

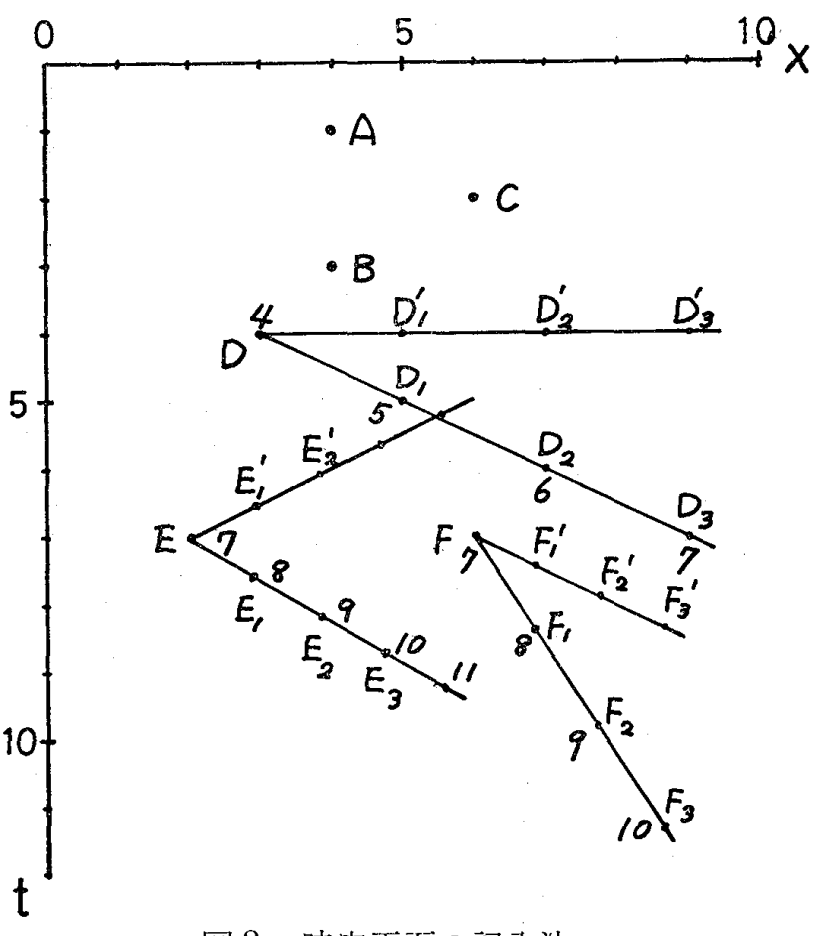

図 2 時空平偭の記入法

$D_{1}, D_{2}$ の如き軌跡をえがく。さらに，A，B，Cの如く時空平面で静止している点は，実際の平面では単位時間 に単位時間長ずつ上方に移動している点である。ところでいま，実際の平面では斜め上方に，単位時間ごとに $E, E^{\prime}{ }_{1}, E^{\prime}{ }_{2}, \cdots \cdots \cdots$ と動いている点 $E$ を考える。ただし $E$ と $E_{1}^{\prime}, E^{\prime}{ }_{1}$ と $E_{2}^{\prime}{ }_{2} \cdots \cdots \cdots$ の縦距離注実際の縦距離 $\triangle y$ を速度 $v$ で割った時間換算距離である。これを時空平面で示すと， $E, E_{1}, E_{2}, \cdots \cdots \cdots+\cdots$ な軌跡が得られ 
る。ここに $\overline{E_{1}^{\prime} E_{1}}$ は 1 単位時間長, $\overline{E_{2}^{\prime} E_{2}}$ は 2 単位時閒長, $\overline{E_{3}^{\prime} E_{3}}$ は 3 単位時間長である。この場合 $E_{1}$ は 時間座標軸では 7.6 の位置にあるが，実際の㭙閒注 8 なのでその数字を記入する。このように斜めまたは上下 方向の移動を記入すると, そのままでは $x$ 方向の移動点, または静止点の時空平面軌跡と区別できないので, 軌 跡の各点にはすべて時間の数值を記入する。このような使いかたをした時空平面の特長は，各時閒々なにおける 各点の位置関係が明確に表現されるといらことである(ただし縦方向は時䦎距離)。たとえば $B$ と $D$ の関係は 時刻 4 においては $(B, D)$ となり，時刻 5 においては $\left(B, D_{1}\right)$ となる。 $E$ と $F$ の関係は時刻 7 においては $(E, F)$ であるが，時刻 8 に乱ては $\left(E_{1}, F_{1}\right)$ となる。なお $D$ 点は時刻 4 において 3 の位圆に存在するが, 時刻 3 において 3 の位置に $B$ 点より 1 単位時間距離 たり後方に存在すると若えてもよい。このような換算 の手段は，実平面の図形を時空平面にうつすとき便利 である。

さてこの時空平面を用いて，嘴讃瀬户宇野，高松間 に打ける, 東西方向に走る主航路の中の, 東航船, 及 び，この主航路を横断する宇高西航路の各船舶につい て, もっとも交通の楅そうする午前 2 時の通航状況を 示したのが第 3 図である。ところでこのよらな多数の 船舶を時空平面で表現するときまず問題となるのは主 航路各船の速力及び進路方向に多少の差暴があること でこのため主航路各船の位置関係は次第に翌化する。 乙か乙必要なのは，横断時の横断船と主航路各船との 位置関係であって，横断に必要な時間住 3 乃至 4 分で 㐫るから，この閒は主航路各船の位置関係はほぼ一定 とみてよい。また横断箅所も時間距離にして約 4 分の 上下幅があるが，その中央基隻位置として使用すれ ぼ，その前後士 2 分時間幅の間では, 主航路各船の位 置関係は固定されているとみてよい。そこで，まずレ 一ダ像の図面上に基準線 $X Y$ を，横断船の 航路分布 のほぼ中央にあたる場所に，主航路に刘して直角に引 く。つぎに時空平面をつくり，その時間軸の単位長は， 主航路の各船の平均速度 $(\mathrm{m} /$ 分) とし, 1 分きざみで $X Y$ 線を水平に入れる。そして，それぞれの時間にレ 一ダ像の画面上の $X Y$ 線上またはその前後で接近し た位置に主航路の船があらわれたら，それらの関係位 置を保ちつつ時空平面上の刘忘する時間の $X Y$ 線上 またはその近辺に，主航路の船を記入する。このよう にして得られた時空平面上の主航路の各船間の関係は, その位置の時間軸で示される時間の前後数分の範囲内 では正しい。

つぎにこの図に横断船を記入する。必要なのは横断 部における主航路各船との位置関係であるから，黒く ぬりつぶしてあるところを基礎にして描いて行く。 $P_{1}^{\prime} P P_{2}^{\prime}, Q_{1}^{\prime} Q Q_{2}^{\prime}$ は通常の平面における $P$ 船及 び $Q$ 船の航跡であり, $P_{1} P P_{2}, Q_{1} Q Q_{2}$ は時空平 面に扝ける $P$ 船及び $Q$ 船の軌跡である。 $P$ 船の $P_{1}$ 位置にお少主航路の $X Y$ 線付近の船船は $A, B, C$

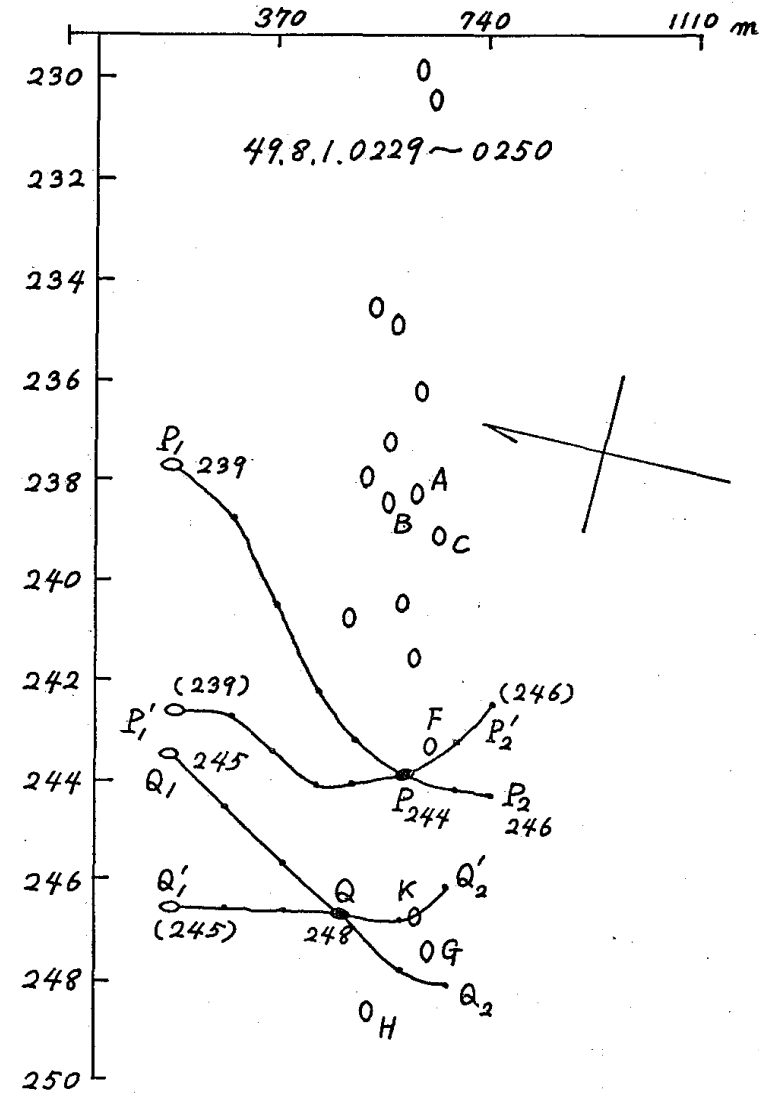

図 3 通航船の実態例

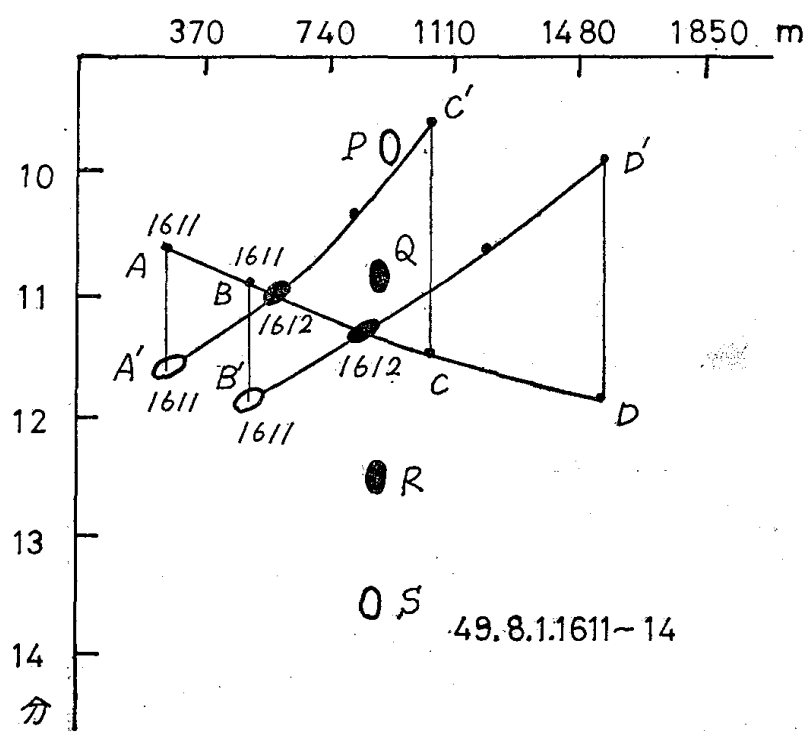

図 4 通航船の害態例 
であって，この近辺の主航路の船舶と $P_{1}$ との位置関係は正しいが， $P_{1}$ と $F$ との位置関係はかなりずれている ものと思われる。しかし $P$ と $F$ の関係，また $P_{2}$ と $F$ の関係は正しい。さて $P$ 船は $F$ の 0.7 分後方を避 航しつつ通過したのであるが，その状況は時空平面では明確に表現されている。また $Q$ 船は $G$ と $H$ の間を割 りこむ形で通過していることがわかる。

この図より明かな如く, 混雑時には主航路の船は 2 列, 3 列をたは 4 列にもなり ( 5 列になることもある), 横断する船は主航路内に入りこんで後, さらに後方避航, 割りこみ, 前方避航を行なって通過する。ところで割 りこみ動作は前方避航と後方避航の組み合わせと考えられるので, 洁局, 避航動作としては前方避航と後方避航 の 2 種を考えればよいことになる。

なお第 4 図は，49.8.1.1611 14k主航路と宇高西航路の交差部で発生したものであるが，時空平面ではA， $\mathrm{B}$ の 2 船が全く同じ軌跡を描いている特異な例である。この場合両船とも，Q船の後方 0.6 分， R 船の前方 1.2 分のところを通っている。交差時刻が1612となっていて時間座標軸と約 1 分ずれているが，これは交差位置が基 準位置より300〜400mほど上方であったことをあらわしている。

\section{4. 交差船列の時空面モデル}

第 5 図は第 3 図に示した実際の状態を考慮して作成したモデルの時空平面の状沉，及び，横断船の通常の空間 における運動状況を示したもので, 図の一番右側に示した 3 列の船列が上方に向って一定の速度で進行する主航 路の船舶をあらわしている。これらの船は前方に 1.5 分, 後方に 1 分の閉塞領域をもつものと寸る。横断船 は左から右に向って進行してくる。横断船が発生した 位置に通行可能なギャップがなければギャップを求め て下方に移動してくる。ギャップがあればそこから主 航路に入りこむ。たとえば $A$ の位置に発生した横断 船は $B$ まで下って，ここに僅かなギャップがあるので 主航路に入りこむ。 $A$ と $B$ の閒の時間距離が「相対待 ち時閒」 $T w$ である。時空平面のハッチングを施した 部分は横断船の通航可能領域を示す。横断船が $B^{\prime} C^{\prime}$, $B^{\prime} D^{\prime} ， B^{\prime} E^{\prime}$ の各線上を走れば，これに対応する通 常平面に招ける横断船の航跡はそれぞれ $B C, B D$, $B E$ の如くなる(ただし 2 本の一点鎖線ではさまれた 部分)。ただいまの場合主航路の船も横断船もすべて 等速とする。このため航跡 $B D$ は時空平面では（一 $45^{\circ}$ ) の傾きの直線 $B^{\prime} D^{\prime}$ となっているが, これょり 谨かに傾きのあさい $B^{\prime} C^{\prime}$ に対応する通常平面の航跡 は大幅に上方に変針しているのに対し， $B^{\prime} D^{\prime}$ より著 しく傾きの大きい $B^{\prime} E^{\prime}$ に対する通常平面の航跡 $B E$ の下方への変針度合はそれほど大きくないことに注意 されたい。また $C^{\prime} D^{\prime}$ の大きさ， $D^{\prime} E^{\prime}$ の大きさを どのように与えるかにより避航の強さを定めることが できる。 $K L, L M, N Q, P Q, R S$ は主航路の閉塞区 間を示す。また $\times \times$ 印の列は主航路が一列となってい るときの状態を示す。 $T U, U V, W X, Y Z$ はこのと きの主航路の閉塞区間を示す。 3 列のときの方がギャ ップの発生量が大きいことがわかる。しかしこれは避 航動作を許容したからであって，避航動作がなければ ギャップの生じる位置などに若干の差ができるけれど

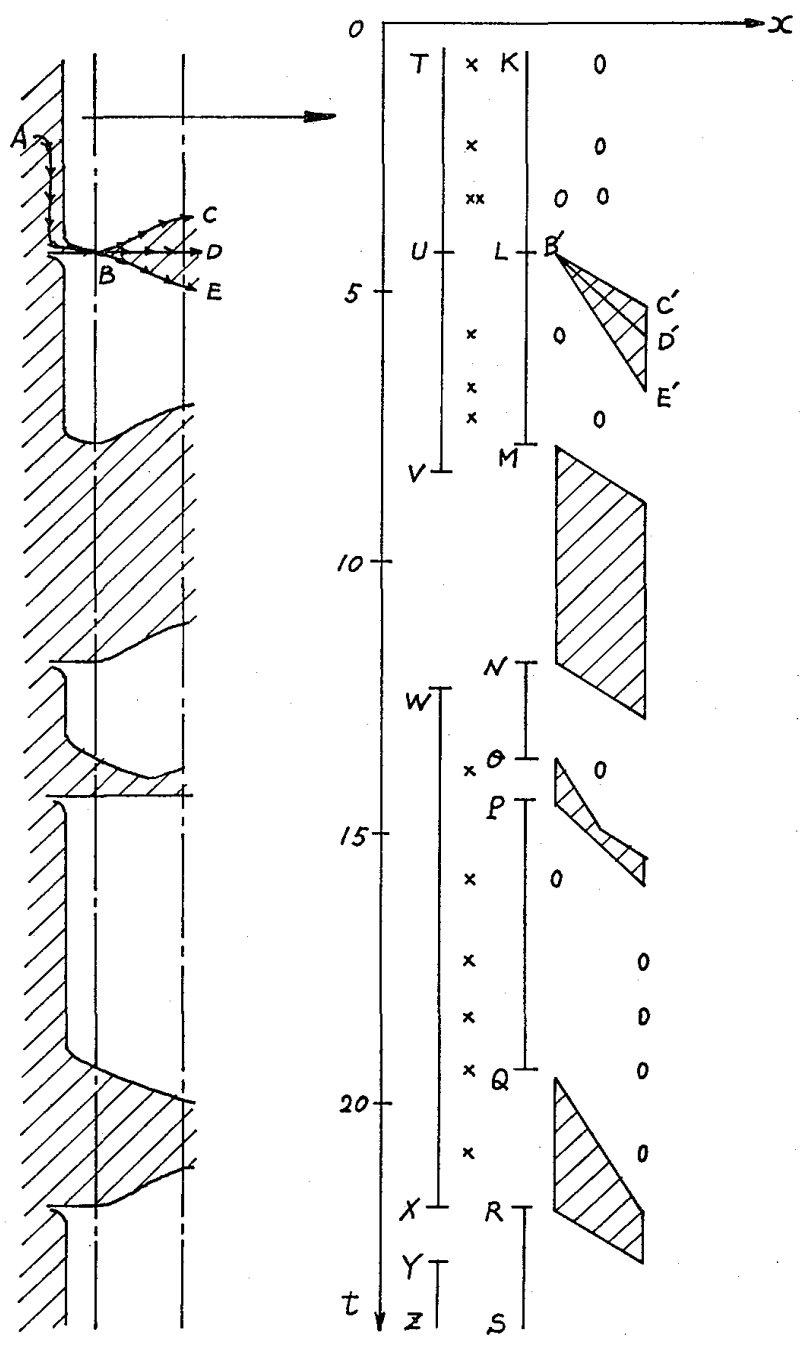

図 5 モデルにおうる横断状況 
も全体としては 1 列の場合と全く同一となる。これは時空平面で各列の船を $45^{\circ}$ の角で第 1 列に投影することにより直ちに理解されよう。なおここでは, 相対待ち時間を，第1列にはいりこむ時としている。この点についても注意し ておく。

さて, 前方避航, 後方避航を行なら結果第 2 列, 第 3 列の船舶の, 第 1 列換 算時間閉塞領域注第 6 図の $\overline{A_{1} A_{2}}, \overline{A_{3} A_{4}}$ の如く短汃くなる。したがってこの ことだけを考えれば，複数レーーンで，かつ各レーンごとに車頭間隔の異なる場 合に相当し理論解も可能であるが，ただいまの場合各船が独立に存在している ときはこのようになるが船と船の組み合せを考えると，条件によって各船の時 間閉塞領域は短かくなったり長くなったりする。このため理論式による解は困 難と考えられるのでモンテカルロ法により解を求めた。つぎにその手法の大要 を示守。

\section{Tw の計算手法}

計算は次の場合について行なった。第 7 図に示すよらに航路幅を $750 \mathrm{~m}, 12$ ノットとすると 2.025 分の時間長となる。そして図示のように第 1 列, 第 2 列, 第 3 列を定める。この場合各列の間隔は0.675分となる。図で $\Delta T_{1}$ は第 1 列の 位置加第 2 列の船に対する，また第 2 列の位置から第 3 列の船に対寸る前 方避航の限界を， $\Delta T_{2}$ は後方避航の限界を示す。ただいまの場合，それぞれ 0.225 分時閒長, 0.450 分時閒長つまり列間隔の $\frac{1}{3}$ 及び $\frac{2}{3}$ とした。なお $2 \Delta T_{1}, 2 \Delta T_{2}$ は第 1 列の位置から第 3 列 の船に対する避航限界を与えるものである。図で $Q B E$ は避航せず直進したときの横断船の航跡，QADはいっ ぱいの前方避航を行なったとき，QCE はいっぱいの後 方避航を行ったときの軌跡である。

主航路の船注次のようにして与える。まず一様乱数を つくり，これを指数乱数に変換し加算して行く。つぎに 配分すべき列をランダムに定め, その列の船にさきの結 果を配分して行く。一方獚断船は閒隔をできるだけせま くして，汃様間隔として，次から次へと発生させる。 本計算では 0.1 分間隔とした。横断の可否は次のように 調べる。なお時間閒塞領域は発生時間からその前方 $T$ までの間として計算した。

(1) まず横断船を 0.1 分間隔で発生させる。ついで その横断船が第 1 列の船の時䦎閉塞領域につきあた るかどらかを調べ，つきあたれば待ち時間を 0.1 分 増やし, かつ，その值の待ち時間発生度数を 1 増や して（1)にもどる。時間閉塞領域につきあたらなけ れば(2)に行く。

（2）第 2 列の船については前方避航，または後方避航 の範囲内で横断できるか否かを調べる。もし通れる ようであれば，前後の船との閒に $T$ 以上のすきま があるかを調べ，Yes であれば第 3 列のチェックに らつる。つまり(3)に行く。Noであれば待ち時間を 0.1 分増やし, かつ, その值の待ち時間の発生度数

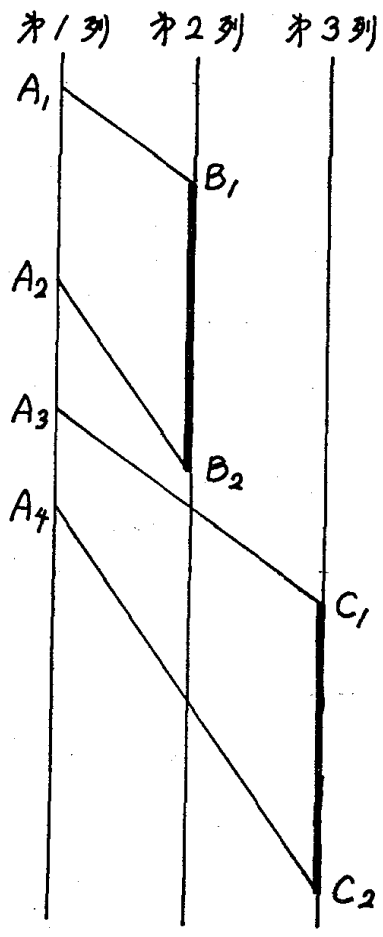

図 6 避航による閉塞領域変化

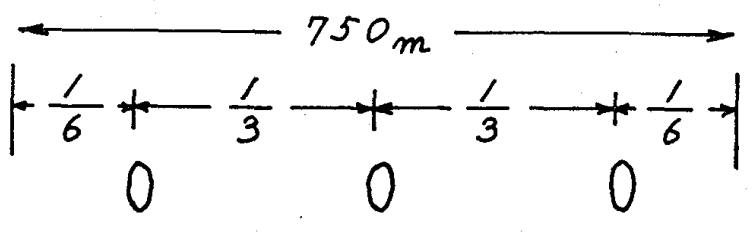

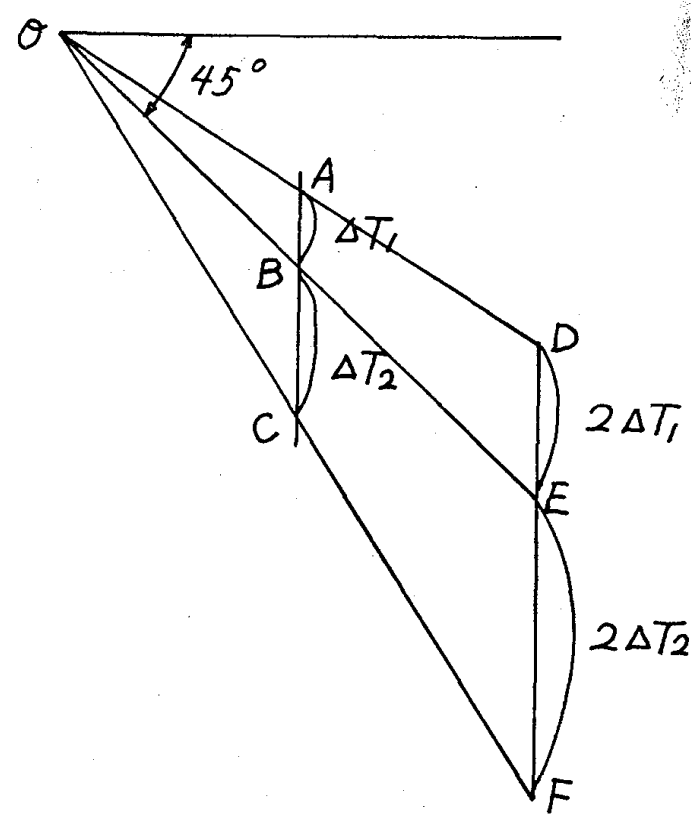

図 7 計算条件の設定図 
を 1 増やして(1)にもどる。

(3) 第 3 列の船に対する避航限界は第 2 列の船の位置で異なってくる。そこで第 2 列の船との関連で避航限界 を与えて通れるか否かを調べ，もし通れるようであれば前後の船との間に $T$ 以上のすきまがあるかを調べ，

Yes であればフリーパスの回数を 1 増やし，待ち時間を０にして(1)にらつる。No であれ洼ち時閒を 0.1 分增やし, その值の待ち時閒発生度数を 1 增やして(1)にうつる。

入力データとしては計算を終了させるときの主航路船発生回数， $T, \lambda, \Delta T_{1}, \Delta T_{2}$ を与える。一様乱数注乗積 合同法により，周期は50000である。演算時間が比較的長くなるので主航路の消費数が10000となるところで計算 を打ち切った。なお各列の前後のつながりのチェックのためめらかじめ各列に80以上の船を発生させておき，そ の 1 隻を消費すれば新たに 1 隻を発生させ，ランダムに定めたいずれかの列に追加する。1 回の計算時間は約 3 hである。

\section{Tw の計算値について}

第 8 図はこのよらにして求めた相対待ら時間密度曲線 $(T=2.5$ 分) である。ただし待ら時間零つまりフリーパ スの密度は別に第 10 図に㧍いて示してある。さて第 9 図はこの曲線を 1 列の場合と比較して描いたもので, 図 で $\overline{Q A}$ はすき閒のできる確率である。 $\overline{Q L}$ が 1 列の場合のすき間のできる確率であるから, 避航動作により $\overline{L A}$

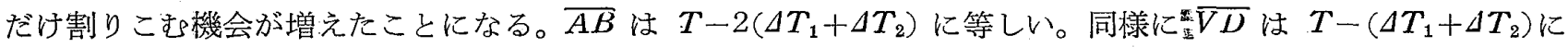
等しく, $\overline{W F}$ は $T$ に等しい。さらに $\overline{X H}$ は $2 T-2\left(\Delta T_{1}+\Delta T_{2}\right)$ に等しい。达た $\overline{B C}$ 第 3 列の船のみが単独 に存在している確率を示し， $\overline{D E}$ は第 2 列の船のみまたは第 2 列に船が存在しても避航効果を考慮した閉塞領域 $T-\left(\Delta T_{1}+\Delta T_{2}\right)$ の第 2 列への投影がすべて第 2 列の船でかくされてしまら場合の確率である。同様に 第 1 列の船のみ，または第 2 列または第 3 列に船が存在しても，避航效果を考慮した閉塞領域の第 1 列への投影 がすべて第 1 列の船でかくされてしまう場合の確率である。そして，CD, EF, GH の部分はすべて直線となり， 区間 $C D$ 注第 3 列の船のみの組み合わせで閉塞領域が構成されているところ，区間 $E F$ は第 3 列及び第 2 列の 船のみの組み合わせで閉塞領域が構成されているところ，区間 $G H$ は第 3 列, 第 2 列及び第 1 列の船の組み合

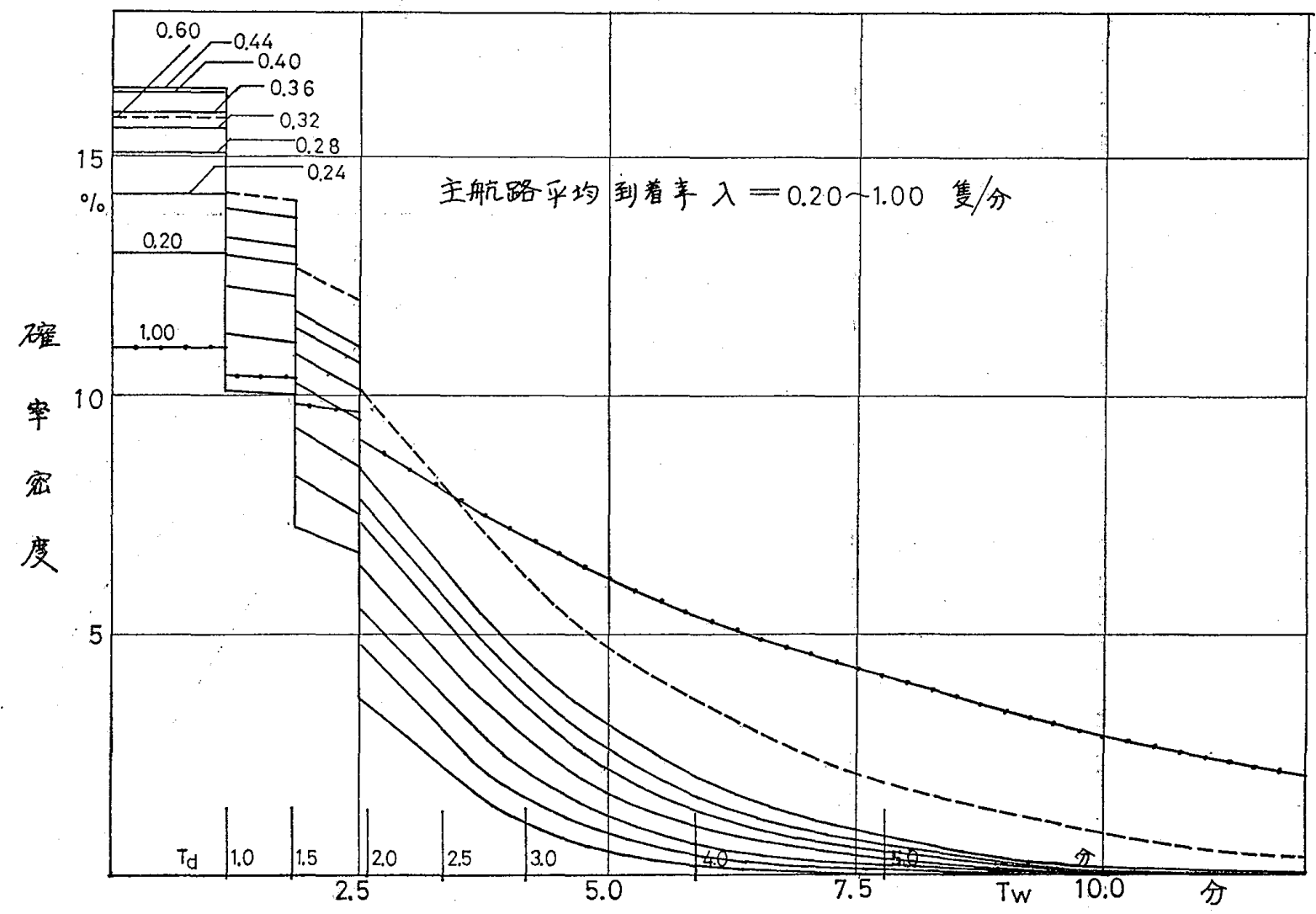

図 8 相対待ち時間 $T w$ と変位時間 $T d$ の確率密度曲線 


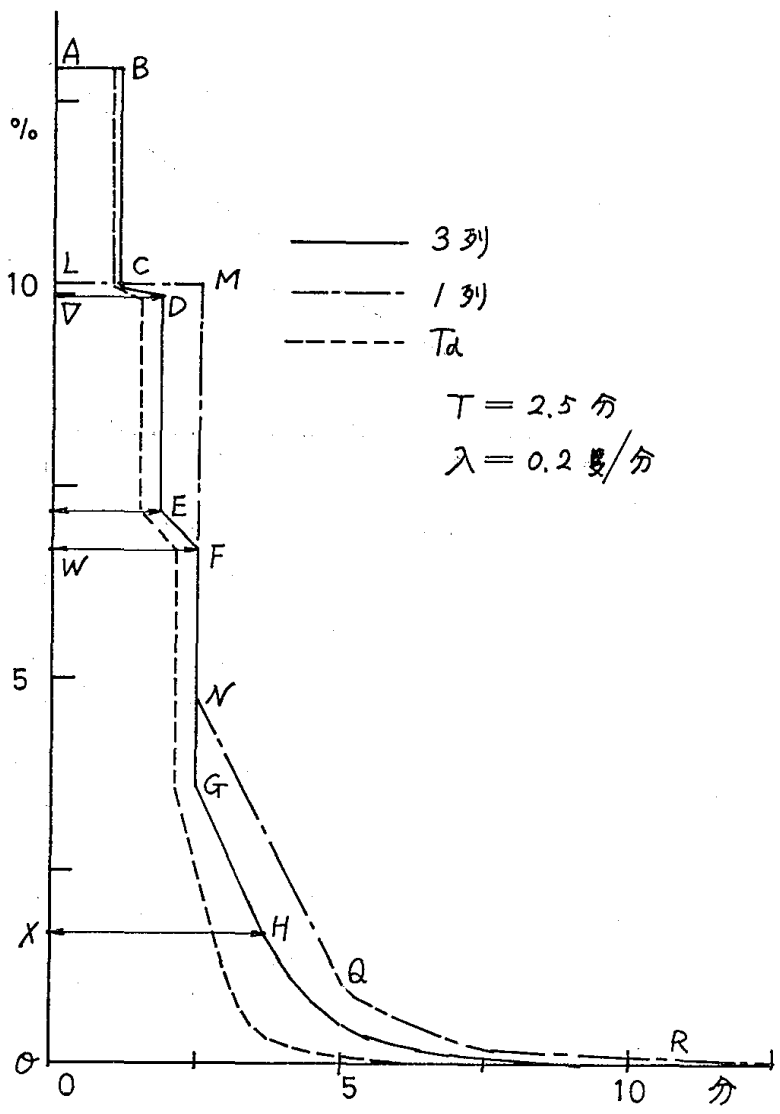

図9 Tw の確率密度曲線の説明図

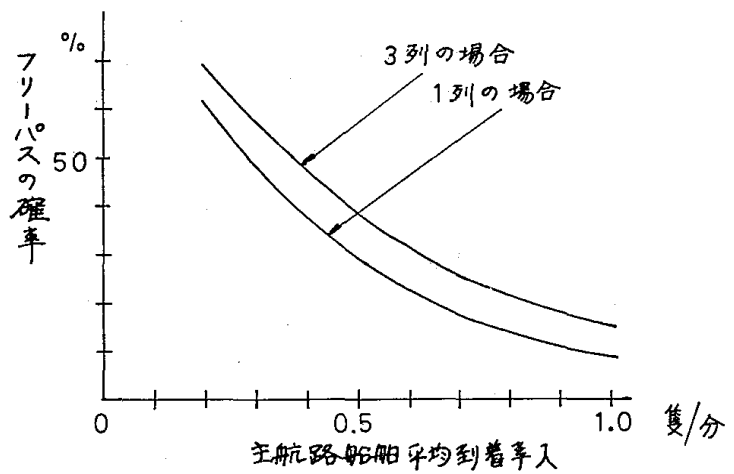

図10 主航路が 3 列の場合及び 1 列の場合の 横切り船のフリーパスの確率の比較

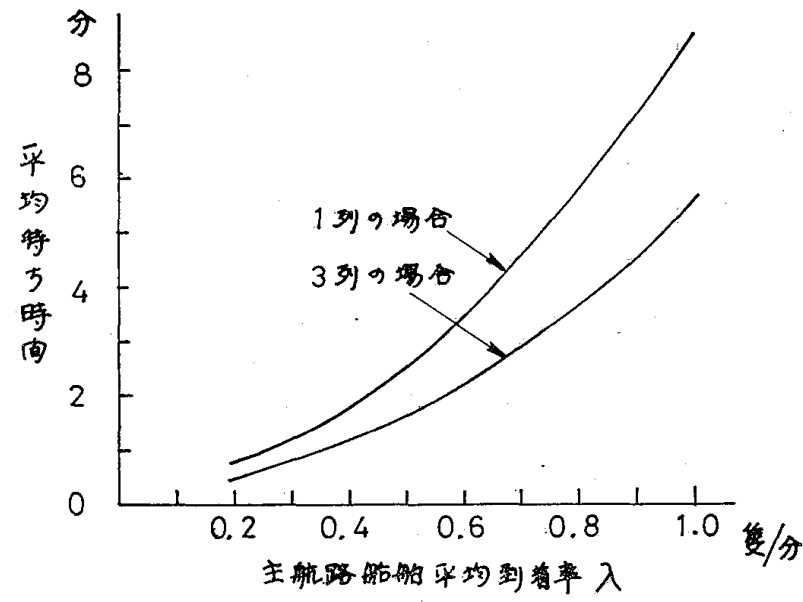

図11 主航路船舶が 1 列の場合及び 3 列の場 合の横切り船の平均待ち時間の比較

わせで閉塞領域が構成されているところである。Hから右側は同様に第 3 列, 第 2 列, 第 1 列の船の組み合わせ で閉塞領域が構成されているが，はじめと拉わりの 2 船のみで連続した閉塞領域が得られず，中間に他の船の閉 塞領域が重なって，はじめて連続した閉塞領域が得られる部分である。1 列の場合の密度曲線 $L M N Q R$ にら べて非常に複雑となるが，その原因は避航動作により各列の実効閉塞領域が変化することにある。

次に第10図はフリーパスの確率を示す。この場合フリーパスといら事は主航路内に待たずつまり避航せず入り こめたことをあらわし，航路内での避航は待ったとは考えない。当然のことではあるが，入が小さいときは 1 列 の場合と殆どかわらないが，入が大になると差異が大になる。なお，この值と第 8 図の曲線の積分の和は 1 とな る。さらに第11図泪対待ち時閒の平均值を示したものである。1列のときに比べて 3 列のときは入に無関係に， ただいまの場合 $66 \%$ といら一定の比率を示している。この数值自身は $\Delta T_{1}, \Delta T_{2}$ の設定の仕方でどのようにも かわるのであまり意味がないが，一定の比率であるという事は理論式を導くとき，一つの手がかりになると思わ れる。

\section{7. $\boldsymbol{t}_{1}-\boldsymbol{t}_{2}$ による補正}

$t_{2}$ を決定するた好に避航時の標準航跡を与えねばならない。このためレーダ像より得られた避航々跡を参照 しつつ，次の如き条件のもとに標隻航跡を設定した。

(1) 船速はかわらないものとする。

（2）避航による船体の回転角は，はじめの $\frac{1}{4}$ 分は 4 度以下，次の $\frac{1}{4}$ 分からは 8 度以下とする。

（3）相手船の後部に船首方向が一致すれば，以後は後部につけて変針する。

（4）避船完了後，相手船の航跡と交差するときは，相手船より 1.0 分の時間距離があるようにする。

（5）避航開始持は，直進した場合の交差位置の 4.5 分前を原則とするが，微小避航，小避航のときは，その度 


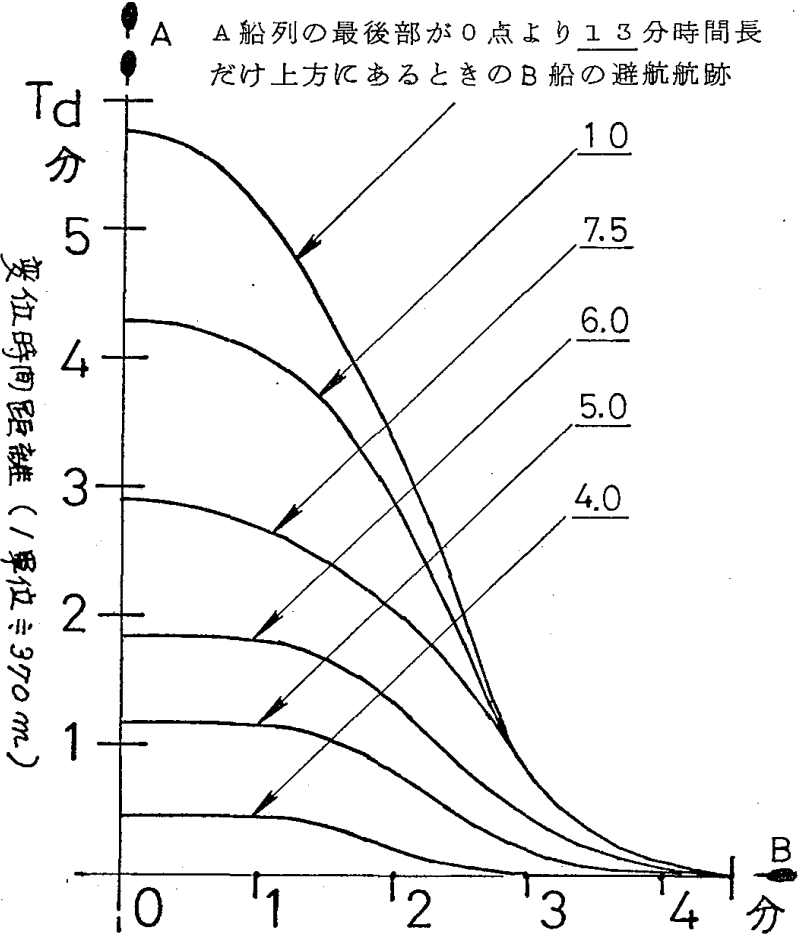

時间長( / 单位 $\div 370 \mathrm{~m}$ )

困12 標淮避航航跡曲線 $t_{2}-t_{1}=0.17 T d^{1.73}$

が得られる。これより $T d$ と $T w$ の関係式として

$T d=T w-0.17 T d^{1.73}$

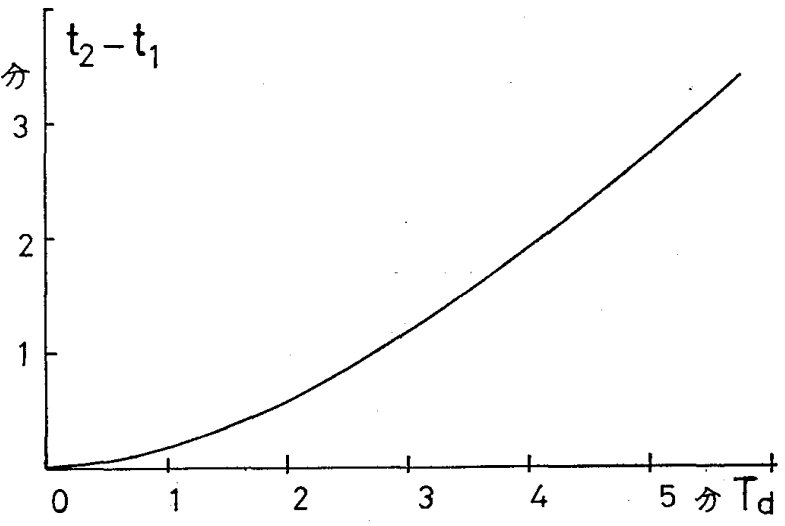

図13 $T d$ と $t_{1}-t_{2}$ の関係

合に応して，3.0分前，3.5分前，または 4.0 分 前とする。

避航開始時刻はできるだけ早いことが望ましいの であるが，微小避航の場合，早く開始すると相手船 に対する時間おくれが大きくなりすぎるので(5)の条 件を入れた。第12図はこのようにして求めた各種の 避航々跡で，第13図はこれより求めた $T d$ と $t_{1}-t_{2}$ の関係を示す曲線である。なおこの曲線より次の実 験式

\section{8. $\quad \boldsymbol{T} d$ の計算值と実测值との対比}

第 9 図の破線はこのようにして求めた $T d$ の密度曲線である。なお第 8 図の $T w$ の曲線に対しては $T d$ 目 盛を付しておいた。これより主航路の船舶の到着率に対して Td がどのようにかわるかが明らかになる。次に実 測值との対比を示す。

第14図は宇高東航路の北航路の航跡図を示したもの で b 図は横断すべき主航路が比較的閑散なとき， $\mathrm{a}$ 図 は主航路がラッシュ状態となっているときを示す。い まこの図に図示の如く座標軸を設ける。この座標の 1 単位は 1 分間における走行距離であって, 標準速力を 12ノットとしているので $370 \mathrm{~m}$ の長さに相当する。座 標の縦軸は主航路西航部の中央よりずらして, 航路分 離線に近いところにとっている。これは待ち㭙間の式 が航路の入り口を基準として求められていることに刘 応させたものである。

第15図は，この基準線上における横断船すなわち北 航船の航跡密度を0.25分時間長ごとに示したものであ る。（数字は隻数で示している）。計測対象としてとり あげた時間帯における主航路の平均到着率は 0.28 隻/ 分（主航路の東航または西航船の平均到着率は 0.23
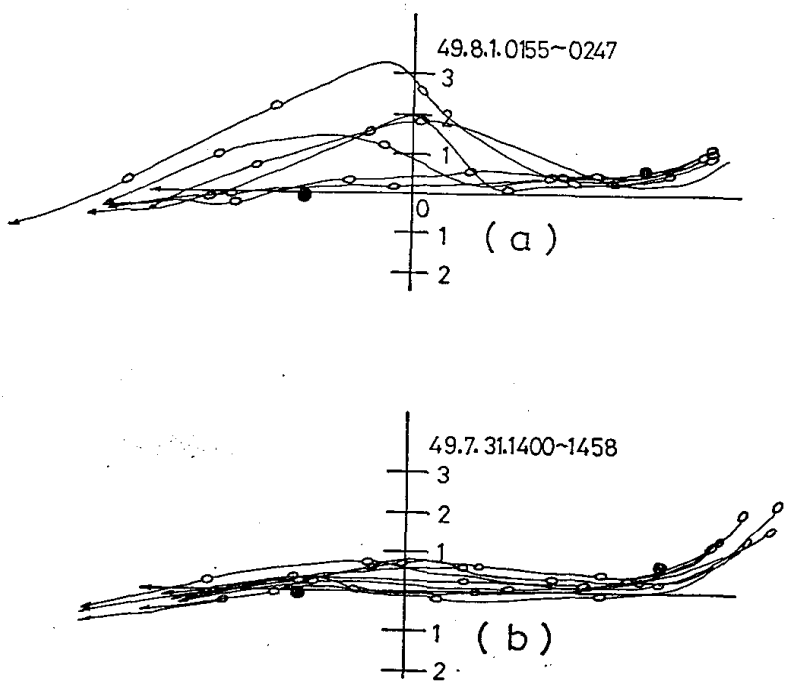

図14 横断船の航路例 
隻/分であるが，この場合の計測対象はいくつかの時 間帯をつなぎ合わせたものであるため, このような数 字となった）である。な打破線で示したものは第 8 図 より求めた， $\lambda=0.23$ 隻/分, $T=2.5$ 分のときの $T d$ の確率密度の理論值（隻数換算）である。この場合理 論值と実測值は全く一致していないように見えるが, 実測值で $T d$ 小さい部分はフリーパスつまり $T w=0$ の場合の航跡が多数含まれているので一致しないのが 当然である。問題は $T d$ の大きいところで, このあ たりになると両者はよい近似を示し，この手法の妥当 性を示していると思われる。

\section{9. 容量の推 定}

本計算は特に混雑時（主航路の）を考慮して求めた ものであるので, $T d$ の 最大值を決定するのに都 合がよい。第 8 図によれ ば $\lambda=0.20$ の時 $T d$ が 4 分時間長をこえる確率 は0.05\%しかない。 $T d$ を 5 分時間長とすると， これ以上の偏位をする確 率つまり $T d=5.0$ より右 側の面積は第16図の如く なる。ただいまの解析で は $T w$ としては航路入口 に入るまでの值をとって いるから, 航路内の後方 避航を考えると，Tw は 0.5 分の増加が見こまれ るので航路内偏位を考慮

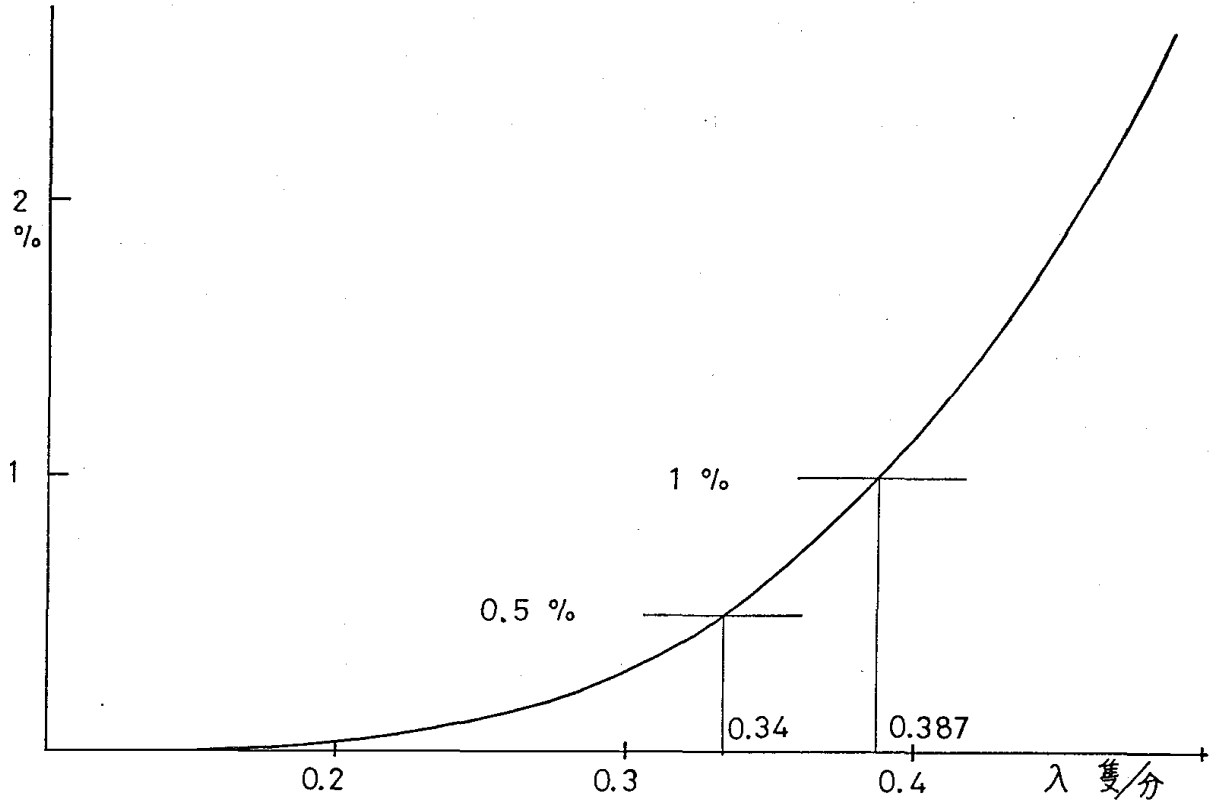

図16 Td が 5 分をこえる確率

した最大実効偏位は 5.5 分に達し得る。よって，Td の $\max$ を 5 分ととることは一忘の限界設定とみてよい。こ の場合 1 日に 1 回 (200回に 1 回)この $\max$ に達する状態を以で最大容量としてみると，第16図よりわかるよ うに $\lambda=0.34$ となり，これは現在の主航路通航量の 1.5 倍弱となる。もっとも 1 日 1 回が限度か， 2 回が限度 か法明確な理由ずけがないので，ただこのようになるとしか言えないが，第16図を見ると入が0.33をこえると $T d$ が 5 分以上になる確率が急激に増大し， $\lambda=0.39$ になると 2 倍になる。この増加ぶりから見ると0.3 から 0.4 の間に限界があると考えるのが妥当ではなからうか。

\section{0. あと がき}

本論文ではせまい海域での容量を制限する主要な要素は $T d$ であるといら立場から, 主航路通航量の関数と して $T d$ を求め, 実測值とかなり近似する結果を得たので, この $T d$ の分布から交差容量の大まかな推定を行 なったが，この中では潮流，漁船などの効果については全く子れていないし，また容量については $T d$ 以外に， 輻そう時の危険の増大についての考慮がなされるい゙きであるう。したがって本計算から直接容量を決定すること はできないが, 容量を定め, あるいは比較する指標としては有效であると考える。 
なお本論文作成にあたっては，日本海難防止協会及び海上保安庁航行安全企画課が合同で記録した，備讃瀬戸 東部の48年及び49年の通航船レーダ写真を資料として全面的に使用させていただいた。ここに厚く謝意を表する。

\section{参考文献}

(1) 待ち行列研究会：応用待ち行列事典（広川書店）, 炤和46年

(2) 井上広滔：交差点 (技術畫院)，昭和46年

(3) F. Garwood : An application of the theory of probability to the operation of vehicular-controlled traffic signals, J. Roy. statist. Soc. Suppl., Vol. 7, 1940

（4）藤井弥平他：船舶の閉塞領域について，日本航海学会論文集35号，昭和41年

（5）大島良三他：横切 Dの避航直径と避航領域，日本航海学会論文集47号，昭和 47 年

(6) 長畑 司：船舶の航路横断にお.待ち合せ問題について，日本航海学会論文集55号, 昭和51年

（7）平野新太郎：船舶の直交交差における待ち時間分布及び交差容量について，日本航海学会論文集57号，昭和 52 年

\section{質疑応答}

久々宮 久（東京商船大）：時空平面とはどのような平面でしよらか。

平野：ここで用いました時空平面は，通常の時空平面と多少異っており，特殊な使いかたをしておりますの で，本文中にその相違点について説明を加えて括きました。 